\title{
Mas-Wrestling is the National Sport of the Sakha Turkic People*
}

\author{
Aikhal Gabyshev** \\ Ilia Cherkashin ${ }^{* * *}$ \\ Elena Cherkashina ${ }^{* * *}$
}

\begin{abstract}
This article deals with the ethnogenesis of the Sakha people and their original affiliation to the Turkic world. The history of creation of maswrestling, the national sport of the Sakha people. By the nature of the motor activity of athletes, mas-wrestling is a high-speed power sport that requires instant considerable physical tension during the bout, technical and tactical preparedness to overcome the attacking actions of the opponent during the bout. The main idea of the competition is that the two athletes, sitting opposite each other and resting their feet in a special support, must pull the stick out of the opponent's hands or pull him or her to their own side. A simple set of tools allows participants to engage in this type of sport almost all year-round, which doesn't require any special sport facilities. This article also presents chronological data on organizational and managerial activities to promote mas-wrestling in the Russian Federation and at the international level, which is characterized by the organization of All-Russian and international Federations, holding of Russian, European, Asian and World Championships. The analysis of the scientific research carried out on the basis of which scientific works on the national sport of mas-wrestling are published is reflected.
\end{abstract}

\section{Keywords}

Turkic people, Sakha, Mas-wrestling, ethnogenesis of the people, competition, research.

\footnotetext{
Date of Arrival: 14 February 2020 - Date of Acceptance: 22 July 2020

You can refer to this article as follows:

Gabyshev, Aikhal et al. "Mas-Wrestling is the National Sport of the Sakha Turkic People." bilig, no. 97, 2021, pp. 201-222.

* Researcher, North-Eastern Federal University, Institute of Physical Culture and Sports - Yakutsk/ Russia ORCID ID: 0000-0001-6050-0259

75-75-75@mail.ru

${ }^{* * *}$ Prof. Dr., North-Eastern Federal University, Institute of Physical Culture and Sports - Yakutsk/Russia; Moscow State Academy of Physical Culture, Research Institute of Information Technologies - Malakhovka/ Russia; Arctic State Agrotechnological University, Department of Physical Education and Sports - Yakutsk/ Russia; Churapcha State Institute of Physical Culture and Sports - Churapcha/Russia ORCID ID: 0000-0002-3015-3003 706037@mail.ru

${ }^{\cdots \cdots *}$ Ass. Prof. Dr., North-Eastern Federal University, Institute of Physical Culture and Sports - Yakutsk/Russia ORCID ID: 0000-0002-3477-8801

churapcha_lena@mail.ru
} 


\section{Introduction}

The preservation of the historical traditions, national identity and national culture of peoples is now a matter of concern to the entire international community. The ethnocultural diversity of sports is now becoming an institutional norm for the promotion and development of the traditional physical activity of peoples. Taking into account that national sports, being an integral part of the original culture of the peoples of the world, can be an effective means of physical and moral rehabilitation of entire ethnic groups. As a result, national sports are an integral part of ethnic culture, which not only must be preserved, but also, through the prism of modern science and practice, transform it into a modern socio-cultural space, taking into account national conditions. The preservation of ethno-cultural traditions and customs, including in the area of sports, is a major response to the process of globalization. And so, through centuries of hard trials, the Sakha ethnic group remains viable thanks to the preservation of cultural heritage, including physical culture. Their rich ethno-cultural traditions in the field of physical education, which were refined in the harsh conditions of the Far North, are of great value and vitality. One of these forms of physical education and a national sport is mas-wrestling, which, as part of the life of the Sakha Turkic people, contributes to the improvement of the physical condition of the population and to the expression of an ethnocultural identity. For many generations, a peculiar system of supporting the physical health of the ethnic group has been developed. In addition to the mutual enrichment of cultures and tolerance, the achievement of peace and harmony, mas-wrestling as a national sport is growing in popularity, is accessible and mass, uniting folk traditions and meeting modern sports standards, and therefore represents a valuable material for the intensive development of human potential through physical education. The harsh living conditions of the Far North helped to come up with a simple set of tools that allowed Sakha men to engage in this type of sport almost all year round (Shamaev 35-40). It does not require any special facilities - you can do it almost everywhere. Its competitive component attracts not only specialists from the Sakha people, but also specialists of the international level, which makes it necessary to address the peculiarities of the formation and development of this sport. The first Mas-Wrestling World Championship, which was held in the capital of the Republic of Sakha in 2014, with 186 participants from 
35 countries, showed the great popularity of this national sport not only among the Turkic population of the Far North, but also all over the world (Cherkashin et al. 23-28).

The modern name of this type of sport was proposed by the first Olympic champion in freestyle wrestling among the Sakha people, Roman Dmitriev. According to him, this name fully conveys the essence of a stick pulling as a form of a combat sport - wrestling through a stick. "Mas" in translation from Sakha language means "a wooden stick", the second part of the word is English "wrestling". So, mas-wrestling (earlier name - "Mas-Tardyhyy" or Stick Pulling) (mas, Sakha - Stick, English - wrestling) is national sport of the Sakha Turkic people, recognized in the Russian Federation (Order No. 546 of the State Sports Committee of the Russian Federation of 16 July 2003 on inclusion in the All-Russian Sports Register), (Kudrin 42-47).

The analysis of literary sources indicates insufficient coverage of scientific works on the history of the formation and development of mas-wrestling. To date, there are four dissertation studies (Zakharov, Development 186, Kudrin 195, Loginov 167, Fedorov 174) dedicated to mas-wrestling. The dissertation work of Kudrin (195) is devoted to the development of technical and tactical actions of qualified athletes in mas-wrestling with the use of technical means. In the work of Zakharov (Development 186) issues related to the development of strength and endurance of arm muscles of qualified mas-wrestlers using technical means are disclosed. The method of improving the technique of attack and defense in mas-wrestling was developed and presented in the dissertation of Loginov (167). Fedorov (174) devoted his dissertation research to the study and development of tools and methods of recovery for qualified athletes in mas-wrestling. Dissertation research is reflected in the monographs of Kudrin (97), Zakharov's textbooks (Mas-Wrestling 101),, and Loginov's (83) methodical manual. Also a training manual was published by a team of authors under the leadership of Cherkashin (205), which reflects the components of sports training in mas-wrestling. One of the first manuals on mas-wrestling was published in the Sakha language "Mas tardyhyyta" in 1997. (Krivoshapkin 84). Later, this author published a monograph on mas-wrestling in 2016, which was devoted to the issues of biomechanical basics of motor action techniques in mas-wrestling, tactics and methods of training mas-wrestlers. 
Features of the organization of training sessions on mas-wrestling among women are reflected in the methodological recommendations of Zakharova (37). Research data aimed at correcting the psychophysiological states of athletes in mas-wrestling using Northern biological products are covered in the monograph by Krivoruchenko et al. (154). Partially mas-wrestling is considered in the monograph of Borokhin (103), which reveals the method of using the means of motor activity of the indigenous peoples of Yakutia in the physical education of students.

In these scientific works, the formation and development of mas-wrestling remains, unfortunately, fragmentary or out of the field of view of modern Russian historical science of physical culture and sports. Works that partially consider the history of the origin of mas-wrestling as a national sport of the Sakha people belong to Kochnev (121), who studied the history of the physical culture movement in the Republic of Sakha (Yakutia). However, even in these works, mas-wrestling is presented in fragments along with the development of other national sports, such as the Yakut national wrestling "khapsağay", national jumps, Northern all-round competitions and others. Consequently, scientific research in mas-wrestling is devoted to the training of athletes: means and methods of improving technical skills, the use of technical means, simulators and extra-training means to improve performance.

The relevance of our research work is that today there are no targeted studies on the analysis of the formation and development of the national sport of the Sakha Turkic people - mas-wrestling, consideration of the issue of preserving it as a historical tradition, identity, and ethno-cultural heritage. Until now, the centuries-old history of mas-wrestling has not been studied, all this, of course, hinders its full development. Reference to the past is always valuable, because its analysis is the best school for understanding the present and foreseeing the future.

Based on the study and analysis of the specialized scientific literature and best practices, the research hypothesis has been formulated, suggesting that the study of the conditions for the formation of the mas-wrestling, its social significance, will help to maintain and further develop this national sport. In this regard, the aim of the research is to study the historical conditions for the formation and development of the national sport of the Sakha Turkic 
people - mas-wrestling.

The following general research methods have been used: analysis, synthesis, comparison, generalization, classification, formalization, systematization of research materials.

\section{Ethnogenesis of the Sakha People - Founders of Mas-Wrestling}

Yakut ethnic group (Yakuts, native name - Sakha; plural - Sakhalar; singular - Sakha) the Turkic people, the indigenous population of the Republic of Sakha. The Yakut ethnic group is called equestrian people, since the main traditional occupation is settled cattle breeding (horse breeding), as well as fishing and hunting. There is also an opinion about the steppe, southern origin of the Sakha, about their initial belonging to the world of Turks of the Great Steppe.

In the research of Ushnitsky (51-66) it is noted that there is an extensive literature on the origin of Sakha. In the course of studying the ethnogenesis of Sakha, various versions were expressed connecting the ancestors of the ethnic group with different ancient and medieval ethnic groups. Soviet and Russian historians achieved certain results in studying the ethnicity of the ancient and medieval ethnic groups in Central Asia and Siberia. Strahlenberg (54-62), as early as the 18th century, pointed out that the Sakha language belongs to the Turkic languages.

Böhtlingk (38-45) expressed an opinion about the greater antiquity of the formation of the Sakha language and people. In his opinion, Sakha are the descendants of a large Turkic nation. So, he believed that the single ProtoTurkic language was first divided into two branches - Turkish and Yakut. The merit of Böhtlingk is a thesis about the extreme antiquity or primordial nature of the Turkic core of the Sakha language.

Miller $(27,39,67)$ also dealt with the origin of the Siberian peoples. According to him, the ancestors of Sakha lived in the vicinity of the Mongols and Buryats and were forced to leave as a result of unsuccessful wars.

Famous poet of the Sakha people and party leader Oyunsky (39-44), based on the interpretation of some toponyms and anthroponyms of the epic olonkho, put forward a hypothesis about the exodus of the Sakha ancestors from the steppes around the Aral Sea. So, Araat Bayğal - the designation 
of the southern sea of the heroes of the Uraangkhay Sakha, in olonkho he identifies with the Aral Sea, the ancestors of Elley (Allay Han) - Argyn and Ayaal - with the Kazakh ethnonym Argyn and Ayaly among the Siberian Tatars, etc. Ubryatova (64-67) put forward the thesis that the Sakha language developed in the process of dissemination in a foreign language environment of some ancient Turkic language, similar to the language of the Orkhon Turks.

According to Gogolev (16-19, 37), in the ancient Turkic era, the ancestors of the Sakha were represented by Kurykans. The participation of the second Turkic-speaking group with the Kypchak heritage can be traced in the ethnogenesis of Sakha. It is believed that these tribes, adhering to the rite of burials with a horse, finally determined the culture and language of the Sakha. Thus, Gogolev is the author of the hypothesis about the participation of Kypchaks in the ethnogenesis of Sakha.

Maloletko (56-59), based on the folklore of the Sakha people about the early inhabitants of the region - khara sayil, tumats and kyrgyz, allowing them to be associated with the ethnonyms of the Sayan-Yenisei Turks, puts forward a hypothesis about the early turkization of Yakutia. As an integral ethnic group, the Sakha was formed on the territory of Yakutia in close contact with local indigenous peoples (Borisova 43-48). Thus, the Sakha (Yakut) ethnic group is the northernmost people of the Turkic language group, so it is believed that because of this isolation, the Sakha language is the closest to the ancient roots of all the Turkic languages.

And so, the place of residence of the Sakha ethnic group is the Republic of Sakha. It occupies almost the entire North-Eastern part of the Asian mainland, extending from North to South for $2000 \mathrm{~km}$. and from West to East for $2500 \mathrm{~km}$. Its territory is about 3 million sq. $\mathrm{km}$. Over $40 \%$ of the territory of Yakutia is located beyond the Arctic Circle. The entire republic is located in the permafrost zone. A soil layer thaws in summer to a depth of 0.4 to $3.5 \mathrm{~m}$. The air temperature fluctuations exceed 100 degrees Celsius (from $+40^{\circ} \mathrm{C}$ in the summer to $-60^{\circ} \mathrm{C}$ in the winter). The pole of cold, Oymyakon $\left(-68^{\circ} \mathrm{C}\right)$ is located in Yakutia. There are Arctic deserts, tundra, forest-tundra, taiga and mountain landscapes. Rivers and lakes, the northern seas are rich in fish, and the taiga (138 million hectares) is home to a wide variety of animals, many of which are not found in other 
regions of Russia. The factors of extreme nature include, along with the cold long winter, vast areas of the taiga, swampy areas, lack of developed land road infrastructure, etc. It is important to note that the climatic and geographical conditions of the Republic of Sakha are characterized by cold, pressure differences, specific photoperiodism, geomagnetic disturbances, solar activity, and strong winds.

The Sakha Turkic people had to keep fit to survive in this harsh climate of the Far North, where there is a constant struggle for survival. In the Far North, the Sakha people brought up the younger generation, using peculiar physical exercises and folk games, which were formed and improved over many generations and served the people to maintain physical health. It is known from oral and literary sources that every young Sakha had to have certain physical qualities in order to be called a real man - bootur. Maswrestling is also mentioned in the oral epic works of the Sakha people olonkho, now recognized by UNESCO as one of the masterpieces of the oral and intangible heritage of mankind (Oyunsky 84-86). In the origin of physical exercise, hunting played a primary role. Hunters must have strength, agility, and stamina. The hunter comprehensively develops motor and volitional qualities - strength, dexterity, speed, stamina, courage and determination (Okladnikov 19, 23, 32). In addition, references to maswrestling are found in the descriptions of researchers in Siberia and the Far East as far back as the 17th century (Alekseev 66-67, 106). In the research work on national sports of the Yakut ASSR, it is noted that historically prevailing factors that contributed to the emergence of peculiar physical exercises, games and competitions among the peoples of the Far North were difficult working conditions in cattle breeding, horse breeding, agriculture, hunting, the complex nature of production activities, and extreme climatic conditions. Over time, these physical exercises, games and competitions created by people have developed into a coherent system of physical education, the main task of which was the struggle for survival, physical development of the ethnic group, preparation for work, respect for the traditions, customs and nature (Kochnev 9-12).

In less than 10 years, a development of national sports of the Sakha people have made a rapid breakthrough. For hundreds of years, the UraangkhaySakha people both summer and winter brightened up their leisure time on the lawn or in the Yakut booth, pulling an unpretentious implement - a 
simple stick. However, for all its external simplicity, this sport has a long history. Overseas Indians and Eskimos have its analogues. There is no such board (for feet) in the Eskimo tug-of-war, called the Eskimo Stick Pull, according to the rules, athletes sit opposite each other and rest their feet against each other. And the Indian Stick Pull is very similar to the old Sakha Turkic fun "mühe byljahyy", where players, standing against each other, try to snatch a wooden stick. There is evidence that the tug-of-war of an iron stick existed in medieval England, some North Caucasian peoples also claim to have some of this kind of games. But nevertheless, it was precisely the Sakha Turkic tug-of-war that has come down to our times in the most preserved form. In addition, Sakha enthusiasts developed competition rules and improved techniques, which helped to turn mas-wrestling into a fullfledged sport at the end of the 20th century (Borokhin 30-32, Kudrin et al. 52-54).

By the nature of the motor activity of athletes, mas-wrestling is a high-speed power sport that requires instant considerable physical tension during the bout, technical and tactical preparedness to overcome the attacking actions of the opponent during the bout. The main idea of the competition is that the two athletes, sitting opposite each other and resting their feet in a special support, must pull the stick out of the opponent's hands or pull him or her to their own side (Cherkashin et al. 35, 52, 84).

\section{Mas-Wrestling among Sakha Population}

Mas-wrestling is very popular among men and women of different ages in the Republic of Sakha. A large number of tournaments organized and held by the Federation contribute to the increase of the number of participants of different age groups - boys, juniors, men, women, veterans. Great interest is aroused not only by the participants themselves, but also among the spectators of sports events. Such major competitions of the Republic of Sakha as the national sports festival "Manchaary Games", held every four years, are very popular among the local population. The program of these competitions includes mas-wrestling.

Analyzing the competitions' minutes and sports groups' data, it should be noted that the number of mas-wrestling participants have been increasing every year from 2010 to 2019 (Figure 1). 


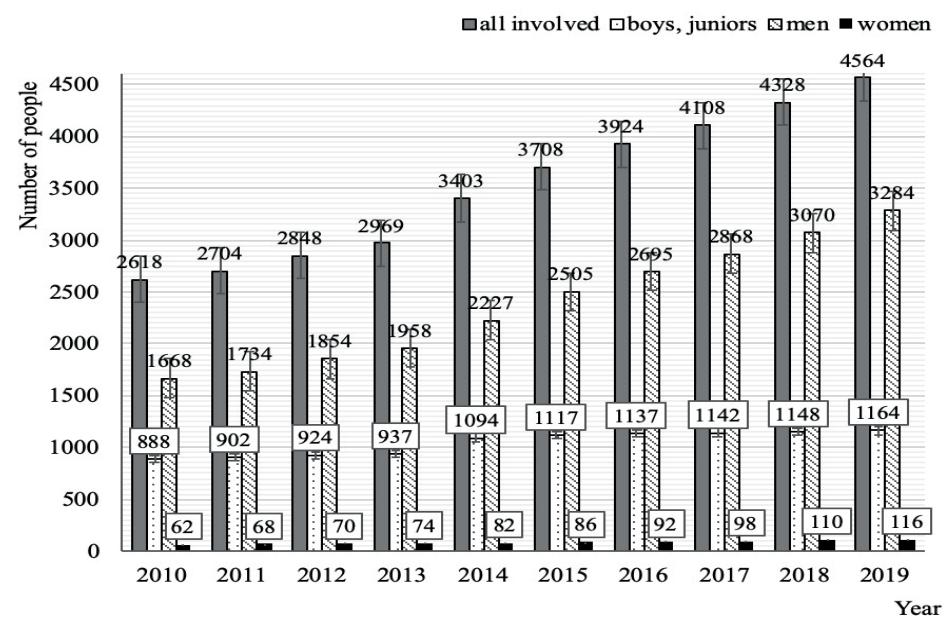

Figure 1. The number of mas-wrestling participants in the Republic of Sakha from 2010 to 2019.

In 2011, compared to 2010, the total number of participants (boys, junior men, junior women, women, men) increased by 3\%, which does not significantly differ from the initial data. During the three years from 2011 to 2013, the number of participants engaged in mas-wrestling in sports groups increased by 3-5\% every year. In 2013, there was a significant increase of $14 \%$ in the number of participants, which significantly differs from the previous year's data by $(\mathrm{p}<0.05)$. This surge was linked to the first World Mas-Wrestling Championship, which was held in Yakutsk, Republic of Sakha, in 2014. This major sporting event contributed to the involvement of more local people in mas-wrestling. In 2014, this figure increased by another $9 \%$ compared to the previous year's data. The growth of participants continued in the following years. In the period from 2015 to 2019 , the number of people who regularly attended mas-wrestling sports groups increased annually by 5-6\%. Over 10 years, the total number of people engaged in mas-wrestling increased by $73 \%$.

If we consider the number of participants according to age groups, the percentage contribution to the total number of people engaged in maswrestling in the Republic differs over the past 10 years in a certain trend. The larger percentage are men, who made up 64 to $72 \%$ of the total number of participants. The next largest age group, which includes boys, junior men 
and junior women. They account for 26 to $34 \%$ of the total number of participants. The third group, women, shows a steady increase every year. Their percentages vary in the range of $2-3 \%$.

Based on the study of competitions' minutes and sports groups' data, the analysis of the dynamics of the number of mas-wrestling participants in various uluses (districts) and cities of the Republic of Sakha showed that over the ten-year period from 2010 to 2019 the involvement of men, boys, junior men, junior women and women in regular mas-wrestling classes has increased. The group of leaders in terms of the number of participants includes uluses and cities, in which their number in 2019 ranges from 201, as in the Nyurbinsky District, to 679 in the Ust-Aldansky District. The number of people involved in the group of leaders ranged from 201. This group included 8 uluses: Ust-Aldansky, Megino-Kangalassky, Churapchinsky, Tattinsky, Suntarsky, Nyurbinsky, Vilyusky and the City of Yakutsk (Figure 2).

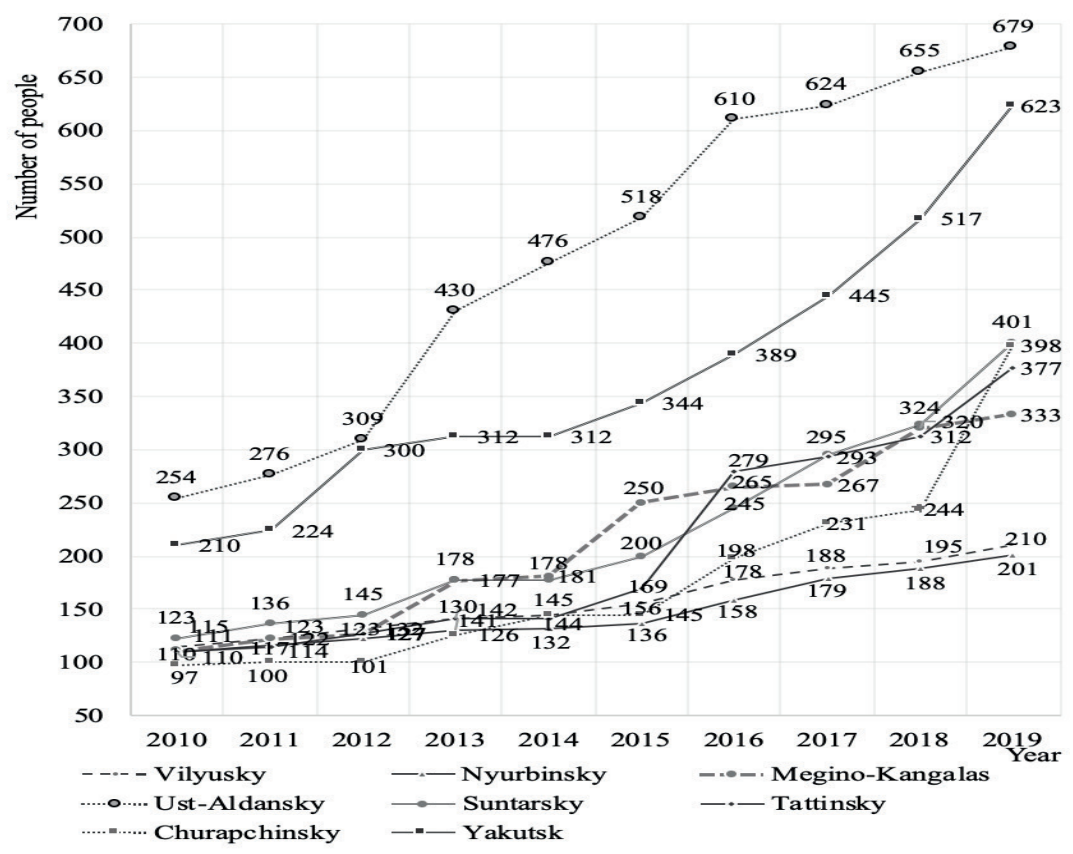

Figure 2. The number of mas-wrestlers in various districts and cities of the Republic of Sakha in the period from 2010 to 2019 (A group of districts and cities with more than 200 participants by 2019). 
The leaders among districts and cities in terms of the number of maswrestlers in 2019 are Ust-Aldansky District, where the number of maswrestlers increased from 254 in 2010 to 679 in 2019, showing a $267 \%$ increase. The second place is after Yakutsk, with 210 participants in 2010, and 623 in 2019, the increase was 297\%. Churapchinsky District is also worth mentioning, with 97 and 398 participants, respectively, showing an incredible $410 \%$ increase.

\section{Government Support for Mas-Wrestling}

The year following the establishment of Soviet regime in Yakutia, in 1923 the Yakut Council for Physical Culture and Sports was established. In 1926, this Council defined the national sports of Yakutia, compiling and describing the first rules for these types of sports. Subsequently, the competition rules have been improved repeatedly. In 1932, a Stick Pulling along with other national sports was included in the program of the all-Yakut Sports Festival.

Since 1968, in order to further develop and promote national sports, the Committee on Physical Culture and Sports of the Republic of Sakha has held a National Sports Festival for the prizes of the legendary hero of the Sakha nation Vasiliy Manchaary. Rural sports games, national sports Championships, and zonal competitions (of the Far East and Siberia) have become a tradition. The first official rules were adopted back in 1945, subsequently classification standards were developed up to the titles of Master of Sports of the Republic of Sakha.

In 2012, at the initiative of the FILA - The International Federation of Associated Wrestling Styles (now UWW - United World Wrestling), the Republican Center for National Sports named after V.Manchaary of the Republic of Sakha and the Association of National Sports and Games of the Peoples of the Republic of Sakha - Sakhaada Sports, competition rules for modern mas-wrestling were developed.

Almost in every locality of Yakutia, mas-wrestling sports clubs have started functioning with fruitful work of enthusiast coaches. The work is done by certified specialists of the Institute of Physical Culture and Sports of the North-Eastern Federal University and the Churapchinsky State Institute of Physical Culture and Sports, where qualified mas-wrestling coaches are trained. 
In 2013, the State Duma of the Russian Federation adopted a bill aimed at supporting national sports. The Act on the Development of National Sports provides the possibility of obtaining State accreditation and acquiring the status of the All-Russian sports federation. The list of such sports of the Ministry of Sports of Russia includes mas-wrestling. Federal standards of sports training for a national sport, which is developed by the corresponding All-Russian Sports Federation, are developed taking into account the specifics of the national sport. They will have to ensure the preservation of the distinctive features of its constituent sports disciplines ("The state"). In 2006, by order of the Government of the Republic of Sakha (Yakutia), the Republican Center for National Sports named after V.Manchaary was established, aiming at getting state support and creating conditions for the development and popularization of national sports, in particular, maswrestling.

Today, popular physical exercises, games and national sports are included in the physical education program for general education and youth sports schools of the Republic of Sakha. From $1^{\text {st }}$ to $11^{\text {th }}$ grade in all secondary schools of the republic in the amount of $25-33 \%$ of the total number of school hours. 52 children's and youth sports schools out of 62 existing ones have national sports departments.

In December 2002, Moscow hosted an All-Russian Mas-Wrestling Federation founding conference, under the auspices of which tournaments were held in the cities of Moscow and St. Petersburg involving athletes from other regions of the Russian Federation.

On June 27, 2005, the All-Russian Public Organization All-Russian MasWrestling Federation was registered by the Federal Registration Service of the Ministry of Justice of Russia. The All-Russian Unified Sports Classification System (USCS of Russia) classification standards and requirements for awarding sports titles are introduced in accordance with established procedure.

\section{First Steps of International Recognition of Mas-Wrestling}

The first events held outside the Republic at the international level:

- in 1992, mas-wrestling was introduced in Whitehorse (Canada) during the Arctic Games; 
- in 1996, in Tokyo (Japan), mas-wrestling presentation was held during the World Sumo Wrestling Championship;

- in 1997, mas-wrestling was presented at the $1^{\text {st }}$ Festival of the Peoples of Siberia and the Far East in the Republic of Tyva (Russia);

- since 1998, the national sport of the Sakha people - mas-wrestling, has been included in the program of the Festival of the Peoples of Siberia and the Far East;

- In 2000, mas-wrestling as a sport was included in the program of the II International Sports Games "Children of Asia», where young athletes from 20 regions of Russia and Asian countries took part in the competition. The games are held once every four years.

- In 2011, mas-wrestling was officially recognized by FILA (International Federation of United Wrestling Styles) as a traditional type of combat sports;

- In 2011, the International Mas-Wrestling Federation public organization was registered in Latvia, which included more than 20 foreign countries. Currently, representatives of 49 countries from five continents of the world are admitted to the International Mas-Wrestling Federation.

\section{Mas-Wrestling in Russia}

Since the creation of the All-Russian Mas-Wrestling Federation, Championships, absolute Championships and Championships of Russia are held annually (Tables 1 ).

The first Russian Mas-Wrestling Championship took place on April 15-17, 2005 in Moscow. Since then, the national Championships are organized annually. The number of participating regions in the Russian Championships has varied from 8 to 22 regions over the past 15 years. However, between 2017 and 2019, the number of participating regions stabilized and increased to 22. The record number of participants in the Russian Championships was recorded in 2006 - 151 people. The period from 2005 to 2013 is characterized by an unstable number of participating athletes in the Russian Mas-wrestling Championships. In 2014, this indicator increases by $191 \%$ compared to the previous year and remains stable over the next years, exceeding the mark of 103 people. 
Since 2007, the absolute Russian Championships for men and women have been held annually. Since 2009, Russian Championships among boys, girls, juniors and veterans have been held annually. Mas-wrestling was included in the program of the first All-Russian sports Games held in September 2013 in Saratov.

Mas-wrestling sports groups and clubs are active in 38 regions of the Russian Federation.

\section{Table 1}

Russian Mas-Wrestling Championships

\begin{tabular}{|c|c|c|c|}
\hline Competitions & Place and year & $\begin{array}{l}\text { Number of } \\
\text { participants }\end{array}$ & Regions \\
\hline I Championship of Russia & Moscow, 2005 & 76 & 14 \\
\hline II Championship of Russia & Krasnoyarsk, 2006 & 151 & 12 \\
\hline III Championship of Russia & Krasnoyarsk, 2007 & 79 & 8 \\
\hline IV Championship of Russia & St. Petersburg, 2008 & 98 & 12 \\
\hline V Championship of Russia & Vladimir, 2009 & 78 & 9 \\
\hline VI Championship of Russia & Smolensk, 2010 & 67 & 8 \\
\hline VII Championship of Russia & Vyazma, 2011 & 86 & 13 \\
\hline VIII Championship of Russia & Suzdal, 2012 & 97 & 13 \\
\hline IX Championship of Russia & Moscow, 2013 & 69 & 12 \\
\hline X Championship of Russia & Moscow, 2014 & 132 & 22 \\
\hline XI Championship of Russia & Moscow, 2015 & 104 & 16 \\
\hline XII Championship of Russia & Tver, 2016 & 108 & 12 \\
\hline XIII Championship of Russia & Dolgoprudny, 2017 & 108 & 20 \\
\hline XIV Championship of Russia & Nalchik, 2018 & 120 & 22 \\
\hline XV Championship of Russia & Cheboksary, 2019 & 121 & 22 \\
\hline
\end{tabular}




\section{Mas-Wrestling on the Global Arena}

In 2011, as part of the II European Sports Games in Šiauliai, the Republic of Lithuania, the I European Championship was held, which was attended by the representatives of 18 European countries. In December of the same year, the I Asian Championship was held in Pune (India) with the participation of athletes from 7 countries.

In 2012, within the framework of the V International Sports Games "Children of Asia" and the Russia-Sports Power International Forum, the I Absolute World Championship was held in Yakutsk with the participation of athletes from 11 countries.

There were also held: the European Championship in 2011 in Siauliai (Lithuania), Asian Championships in 2011 in Pune (India) and 2014 in Tashkent (Uzbekistan), World Cups in 2012 and 2013, consisting of several stages, were held in Moscow, St. Petersburg and Dubai (UAE). In 2014, mas-wrestling was presented at the world-class multi-sport event Arnold Sport Festival in Columbus, Ohio, USA. As part of the year of the RussianJapanese exchange in the field of martial arts, on October 4-6, 2014, a mas-wrestling presentation was held in Nippon Budokan in Tokyo (Japan).

In December 2011, the International Mas-Wrestling Federation was registered in Latvia, having membership in more than 20 countries. $\mathrm{Mr}$ Akimov A.K., Permanent Representative of the Republic of Sakha to the President of the Russian Federation in Moscow, was elected President of the Association.

In November 2014, the first Mas-Wrestling World Championship was held in Yakutsk, the Republic of Sakha under the auspices of the United Nations Educational, Scientific and Cultural Organization (UNESCO). The world champion in mas-wrestling was the Russian National team, which won 12 gold, 7 silver and 3 bronze medals. The III Congress of the International Mas-Wrestling Federation was held as part of the Championship, which adopted a Memorandum on the development of world mas-wrestling ("Mas-wrestling"). 


\section{Conclusion}

The formation and development of mas-wrestling include the following: natural and climatic, ethno-social and historical conditions. We have shown that the harsh climatic and geographical conditions of the Far North, greatly affecting the physical state of the people, life expectancy and its quality, health, historical events, including wars, and traditions, customs of the people residing in the Republic of Sakha, have always been making special demands to men, which was manifested in their desire to be nimble, strong, fast and tough. And one of the types of motor activity was mas-wrestling. Living in extreme climatic conditions of the Far North, it was vital for the Turkic people of Sakha to maintain good physical shape in a constant struggle for survival. Educating the younger generation, they used peculiar physical exercises and folk games, which were formed and improved over many generations and served the people to maintain physical health.

The emergence of a variety of physical exercises, games and competitions among the peoples of the Far North was influenced by difficult working conditions in agriculture, cattle and horse breeding. Of course, physical exercises were also influenced by hunting, without which it was impossible to survive in extreme climatic conditions. The main physical qualities for hunters were strength, endurance and agility, which they developed through original physical exercises.

Mas-wrestling by the nature of motor activity is a high-speed power sport that requires instant considerable physical tension during the bout, technical and tactical preparedness to overcome the attacking actions of the opponent during the bout. The main idea of the competition is that the two athletes, sitting opposite each other and resting their feet in a special support, must pull the stick out of the opponent's hands or pull him or her to their own side. A simple set of tools allowed Sakha men to engage in this type of sport almost all year-round, which doesn't require any special sport facilities, you can do it almost everywhere: indoors, in the yard, on a glade.

Mas-wrestling, as a national sport with its own customs and traditions, is an integral part of physical education and occupies one of the leading positions in the ethno-pedagogics of the Sakha Turkic people. In the tradition of national education physical education pays great attention to 
the phenomenon, providing the person's life activity, that his physical fitness is not an end in itself, but as a necessary condition for life and independent participation in work activities, that physical training (culture) is an integral part of spiritual culture of the people and physical development occupies an important place in the social formation of man as the basis of his physical and spiritual health. One of the key components of ethnic pedagogy that are directly related to education is folk games that are passed down from generation to generation. They reflect the way of life of people, their daily life, work, ethnic ideas of honor, bravery and courage.

The positive dynamics of mas-wrestling involvement indicators among the population of different ages of the Republic of Sakha for the period from 2010 to 2019 was determined. The indicator of the number of people engaged in mas-wrestling in youth sports schools, sports groups organized by the Republican Center of National Sports named after V.Manchaary, the Republican and District Federations of Mas-Wrestling in different cities and villages of the Sakha Republic in 2010 was 2618 people (men-1668, boys, junior men, junior women-888, women-62), in 2019 this figure increased by $174 \%$ and made up 4564 people (men-3284, boys, junior men, junior women-1164, women-116).

The development of mas-wrestling not only as a motor and leisure activity, but a national sport happened on the $20^{\text {th }}$ century and still going on in the $21^{\text {st }}$ century., which are rich in events directly related to it. These include: the approval of mas-wrestling as a national sport in 1926, its inclusion in the program of major Republican Sports Festivals since 1932, the approval of the first official rules of competition in 1945, in 2003, the inclusion of mas-wrestling in the All-Russian Register of Sports, the organization in 2005 of All-Russian Mas-Wrestling Federation. In the same year, maswrestling was included in the All-Russian Unified Sports Classification System (USCS of Russia). In accordance with the established procedure, classification standards and requirements for awarding sports titles in maswrestling are introduced. Since 2009, Russian Championships among boys, girls, juniors and veterans have been held annually. In 2011, the International Mas-Wrestling Federation public organization was registered in Latvia, which includes more than 20 foreign countries. The European and Asian Championships were also held this year. In 2012, competition 
rules for modern mas-wrestling were developed. In 2014 the first MasWrestling World Championship was held in Yakutsk (Republic of Sakha). Also "Children of Asia" Sports Games program included mas-wrestling competitions in 2000, 2004, 2008, 2012 and 2016.

The authors of existing research in mas-wrestling emphasize that in this sport it is necessary to improve various components of the sports training system (Kudrin 97, Zakharov (Development 186), Loginov 167, Fedorov 174, Krivoshapkin 87). In our study, we considered mas-wrestling from the position of studying the conditions of its origin and development features. Partially in the works of the authors (Kudrin 195, Zakharov (Development 186), Loginov 167, Fedorov 174, Krivoshapkin 87) the interpretation of the concept of mas-wrestling is mentioned, its appearance in the international movement. We have expanded the data on the natural and climatic conditions of mas-wrestling development, which are fragmentally mentioned in the works of Kudrin et al. (97), Cherkashin et al. (205). In the works of Kudrin (195), Zakharov (Development 186), Loginov (167), the results of competitive activity of individual athletes participating in experimental studies are presented. The authors focus on the training process of athletes in mas-wrestling, without mentioning the ethnic and social significance of this national sport. In our study, we studied the number of people engaged in mas-wrestling in the Republic of Sakha, which shows the social significance of the Turkic ethnic group of the Sakha people in modern conditions, the popularity of this national sport. We determined the place of mas-wrestling in the ethno-pedagogics of traditional physical education of the Sakha people and considered organizational and methodological aspects of the development of mas-wrestling in modern socio-economic conditions.

\section{References}

Alekseev, Anatoly Nikolayevich. "To the Question of the Origin of the Yakut People." Philology, no. 12, 1994, pp. 66-67.

Alekseev, Anatoly Nikolayevich. Ancient Yakutia. The Iron Age and the Middle Ages. History and Culture of East Asia. Publishing House of the Institute of Archaeology and Ethnography SB RAS, 1996.

Böhtlingk, Otto Von. Über die Sprache der Jakuten. Buchdruckerei der Kaiserlichen Akademie der Wissenschaften, 1851.

Borisova, Ulyana Semenovna. "On the Experience of a Forecast Study of the 
Development of the Republic of Sakha: Expert Opinion." Theory and Practice of Social Development, no. 6, 2013, pp. 43-48.

Borokhin, Mikhail Ilyich. "Use of Motor Means of the Indigenous Peoples of Yakutia in the Physical Education of Students." Theory and Practice of Physical Education, no. 10, 2012, pp. 30-32.

Borokhin, Mikhail Ilyich. Method of using the Means of Motor Activity of the Indigenous peoples of Yakutia in the Physical Education of Students. NEFU Publishing House, 2016.

Cherkashin, Ilia Afanasievich et al. Sports Training in Mas-Wrestling. Dani-Almaz Publishing House, 2018.

Fedorov, Eduard Pavlovich. Restoration of Qualified Wrestlers in the Year-long Training Cycle. The dissertation on competition of a scientific degree of Candidate of Pedagogical Sciences. Churapcha State Institute of Physical Culture and Sports, 2018.

Gogolev, Anatoly Ignatievich. Yakuts: Problems of Ethnogenesis and the Formation of Culture. YSU Publishing House, 1993.

Kochnev, Valery Panteleimonovich. National Sports of the Yakut Autonomous Soviet Socialist Republic. YSU Publishing House, 1980.

Kochnev, Valery Panteleimonovich. History of the Physical Culture Movement of the Republic of Sakha (Yakutia). NEFU Publishing House, 2015.

Krivoruchenko, Elena Viktorovna. Correcting the Psycho-Physiological Conditions of Athletes Using Bio-Products From Northern Raw Materials (In the Case of Hapsagay And Mas-Wrestling). NEFU Publishing House, 2015.

Krivoshapkin, Petr Ivanovich. Mas tardyhyta. NEFU Publishing House, 1997.

Krivoshapkin, Petr Ivanovich. Mas-Wrestling: biomechanical Basics of Technique, Tactics and Techniques. NEFU Publishing House, 2016.

Kudrin, Egor Petrovich. Development of technical and tactical actions of qualified athletes in mas-wrestling with the use of technical means. The dissertation on competition of a scientific degree of Candidate of Pedagogical Sciences. North-Eastern Federal University, 2017.

Kudrin, Egor Petrovich. Mas-wrestling: Technical and Tactical Actions. NEFU Publishing House, 2018.

Loginov, Vyacheslav Nikolayevich. The Basics of Sport Training in Mas-Wrestling. ChGIFCiS, 2017.

Loginov, Vyacheslav Nikolayevich. A Method of Improving Attack and Defense Techniques in Mas-Wrestling. The dissertation on competition of a scientific degree of Candidate of Pedagogical Sciences. Churapcha State Institute of Physical Culture and Sports, 2020. 
Maloletko, Alexey Mikhailovich. The Ancient Peoples of Siberia. Ethnic Composition According to Toponymy. Pre-Kagan Turks. Tomsk State University, 2004.

"Mas-wrestling: Strength. Mind. Tactics". International Mas-Wrestling Federation, 16.04.2018, https://www.mas-wrestling.com/ru/media/publish/22374/.

Miller, G.F. Description of the Siberian Kingdom. Publishing House of the USSR Academy of Sciences, 1937.

Okladnikov, Alexey Pavlovich. History of the Yakut Autonomous Soviet Socialist Republic. Yakutia Before Joining the Russian State. The science, 1955.

Oyunsky, Platon Alexeyevich. "Sakha Uoskeebite." Cholbon, no. 5, 1928, pp. 3944.

Oyunsky, Platon Alexeyevich. Nyurgun Bootur Swift. Olonkho, 1975.

Shamaev, Nikolay Kalinovich. Fundamentals of the Methodology of the Lesson System of Physical Education in Schools of the North. YSU Publishing House, 1999.

Strahlenberg, Philipp Johann. Das Nord-und Ostlichen Theil von Europa und Asia. Ver-fegung Des Autoris, 1730.

"The state Duma has adopted a bill aimed at supporting national sports". TASS, 11.12.2013, https:///tass.ru/sport/823885/.

Ubryatova, Elizaveta Ivanovna. Historical Grammar of the Yakut Language. Yakut Book Publishing House, 1985.

Ushnitsky, Vasily Vasilyevich. "The Origin of Sakha: Background.” New Studies of Tuva, no. 2, 2014, pp. 51-66.

Zakharov, Alexander Alexandrovich. Mas-Wrestling. NEFU Publishing House, 2011.

Zakharov, Alexander Alexandrovich. Development of strength and stamina of muscles of skilled Mas-wrestlers with the use of technical means. The dissertation on competition of a scientific degree of Candidate of Pedagogical Sciences. North-Eastern Federal University, 2017.

Zakharova, Yana Yuryevna. Special Features of The Organization of Training Sessions In Mas-Wrestling Among Women. NEFU Publishing House, 2011. 


\title{
Mas Güreşi - Türk Saha Halkının Milli Sporu*
}

\author{
Aikhal Gabyshev $^{* *}$ \\ Ilia Cherkashin ${ }^{* * *}$ \\ Elena Cherkashina ${ }^{* * * *}$
}

\begin{abstract}
$0 \ddot{z}$
Makalede, Saha halkının etnogenezi, Türk dünyasına ait olduğuna dair soruları tartışılmaktadır. Saha halkının milli sporu olan mas güreşinin ortaya çıma tarihi incelenmektedir. Bu spor ile uğraşan sporcuların bedensel hareketlerine göre, mas güreşi, mücadele anında rakibin saldırı eylemlerinin üstesinden gelmek için önemli olan ani fiziksel güç kullanımı, tekniksel ve taktiksel hazırlık gerektiren bir «hız gücü sporu» olarak nitelendirebiliriz. Musabakanın özü, yüz yüze oturan iki yarısmacı ayaklarını sabit bir şekilde özel bir tahtaya dayandırarak rakibin ellerinden bir ağaç çubuğu veya rakibi kendi tarafına çekmesinden oluşmaktadır. Ayrıca bu çalışmada, hem Rusya Federasyonu’ndaki, hem uluslararası alanında mas güreşini teşvik etmek için yapılan organizasonel ve yönetsel faaliyetlerle ilgili kronolojik verileri sunulmaktadır. Böylece, Rusya ve Uluslararası Mas Güreş Federasyonu'nun, Rusya, Avrupa ve Asya’da dünya şampiyonalarının düzenlenmesi ile karakterize edilmektedir. Bu çalışma, milli spor türü olarak mas güreşi ile ilgili yayınlanan tüm bilimsel makaleleri esasına dayanılarak yapılan bilimsel araştırmaların analizini yansıtmaktadır. Anahtar Kelimeler

Türk halkları, Saha, mas güreşi, halk etnogenezi, yarışma, araştırma.
\end{abstract}

Geliş Tarihi: 14 Şubat 2020 - Kabul Tarihi: 22 Temmuz 2020

Bu makaleyi şu şekilde kaynak gösterebilirsiniz:

Gabyshev, Aikhal et al. "Mas-Wrestling is the National Sport of the Sakha Turkic People." bilig, no. 97, 2021, pp. 201-222.

** Araştırmacı, Kuzey-Doğu Federal Üniversitesi, Fiziksel Kültür ve Spor Enstitüsü - Yakutsk/Rusya ORCID ID: 0000-0001-6050-0259

75-75-75@mail.ru

*** Prof. Dr., Kuzey-Doğu Federal Üniversitesi, Fiziksel Kültür ve Spor Enstitüsü - Yakutsk/Rusya; Moskova Devlet Fiziksel Kültür Akademisi, Bilgi Teknolojileri Araştırma Enstitüsü - Malakhovka/Rusya; Arktik Devlet Agroteknoloji Üniversitesi, Beden Eğitimi ve Spor Bölümü - Yakutsk/Rusya; Churapcha Devlet Fiziksel Kültür ve Spor Enstitüsü - Churapcha/Rusya

ORCID ID: 0000-0002-3015-3003

706037@mail.ru

**** Ass. Prof. Dr., Cherkashina Elena, Kuzey-Doğu Federal Üniversitesi, Fiziksel Kültür ve Spor Enstitüsü

- Yakutsk/Rusya

ORCID ID: 0000-0002-3477-8801

churapcha_lena@mail.ru 


\title{
Мас-рестлинг - национальный вид спорта тюркского народа саха*
}

\author{
Айхал Габышев \\ Илья Черкашин \\ Елена Черкашина
}

\begin{abstract}
Аннотация
В статье рассматриваются вопросы этногенеза саха, изначальной принадлежности народа саха к тюркскому миру, а также история возникновения национального вида спорта народа саха - масрестлинга (мас тардыһыы). Мас-рестлинг по характеру двигательной деятельности спортсменов является скоростно-силовым видом спорта, требующим мгновенных значительных физических напряжений в схватке, технико-тактической подготовленности для преодоления атакующих действий соперника в поединке. Суть соревнований состоит в том, что два спортсмена, сидя друг против друга и упираясь ногами в специальный упор, должны вырвать палку из рук соперника или перетянуть его на свою сторону. Также в работе представлены хронологические данные деятельности по популяризации мас-рестлинга в Российской Федерации и на международном уровне, выражающиеся в деятельности Всероссийской и международной федераций, проведении чемпионатов России, Европы, Азии и мира. Отражен анализ проведенных научных исследований, на основе которых изданы научные труды по национальному виду спорта народа саха - мас-рестлингу.

Ключевые Слова

Тюркский народ, саха, мас-рестлинг, этногенез, соревнование, исследование.
\end{abstract}

\footnotetext{
* Поступило в редакцию: 14 февраля 2020 г. - Принято в номер: 22 июля 2020 г.

Ссылка на статью:

Gabyshev, Aikhal et al. "Mas-Wrestling is the National Sport of the Sakha Turkic People." bilig, no. 97, 2021, pp. 201-222.

** Исследователь, Северо-Восточный федеральный университет, институт физической культуры и спорта - Якутск/Россия ORCID ID: 0000-0001-6050-0259

75-75-75@mail.ru

*** Проф., д-р, Северо-Восточный федеральный университет, институт физической культуры и спорта - Якутск/Россия;

Московская государственная академия физической культуры, научно-исследовательский институт информационных технологий - Малаховка/Россия;

Арктический государственный агротехнологический университет, кафедра физического воспитания и спорта - Якутск/Россия;

Чурапчинский государственный институт физической культуры и спорта - Чурапча/Россия ORCID ID: 0000-0002-3015-3003

706037@mail.ru

**** Доц., д-р, Северо-Восточный федеральный университет, институт физической культуры и спорта - Якутск/Россия

ORCID ID: 0000-0002-3477-8801

churapcha_lena@mail.ru
} 